Leitheiser Fruzsina ${ }^{71}$

\title{
VÁRANDÓSKORI MUNKAVÁLLALÁSI TERVEK MEGVALÓSULÁSA ÉS A KORAI MUNKAVÁLLALÁS JELLEMZÖI
}

\begin{abstract}
Although views related to the traditional perception of social roles are still widespread in Hungary, the participation of women in the labour market has become more and more typical. However, in many cases having children can pull women out of the labour market for years, breaking their career paths. Mothers are more and more disadvantaged by the increase in time spent away, as the knowledge they need to do their job does not develop further or becomes obsolete, which can hold back career prospects in terms of professional development and even lead to a loss of income. Higher education, married marital status, longer previous work experience and higher personal income increase the chances of early return to the labour market, however, in the case of a single (divorced) marital status or married relationship/ partnership, the partner's high income and higher number of children may reduce the chances of this. The aim of this study is to present the development of the planned period of re-employment assumed during pregnancy half a year after the birth - not a typical pathway in Hungary, which concerns only about 3,6\% of mothers - and to map the factors along which the early return to the labour market after the birth can be characterized. All these are determined based on the available literature of the topic and the data of the first (pregnancy) and second (occurring at the age of six months) wave of the longitudinal panel research Cohort '18 Hungarian Birth Cohort Study launched by the Hungarian Demographic Research Institute in early 2018.
\end{abstract}

\section{Bevezetés}

A nők fokozott munkaerőpiaci szerepvállalása a XX. századi társadalmak iparosodási folyamataival hozható összefüggésbe, amely során a háztartásokban egyre jellemzőbbé vált a kétkeresős családmodell, azaz a nők bevonódása a kereső tevékenységbe. A gazdasági érdekek mellett azonban a nők munkavállalásának elterjedését a bennük kibontakozó függetlenedési vágy, valamint az egyéni karrier építése iránti igény is motiválta (B. Bába 2014). Ennek megfelelően Magyarországon ugyan olyan magától értetődő a nők munkaerőpiaci jelentléte mint a férfiaké, azonban ez az állítás csak addig állja meg a helyét, amíg a nők nem válnak anyává. Egy gyermek érkezése ugyanis nagyban megváltoztatja az anya munkaerőpiaci magatartását, mivel a szülést követően jellemzően ők maradnak hosszútávon otthon, az apák pedig magukra vállaljak a fő kenyérkereső szerepét (Makay 2018). A munkaerőpiactól távol

\footnotetext{
${ }^{71} \mathrm{Az}$ elemzés elkészültét támogató az EFOP-3.6.3-VEKOP-16-2017-00007 azonosítószámú, „Tehetségből fiatal kutató. A kutatói életpályát támogató tevékenységek a felsőoktatásban” megnevezésű projekt a Széchenyi 2020 program keretében, európai uniós (Európai Szociális Alap) társfinanszírozással valósult meg.

A tanulmány továbbá az Innovációs és Technológiai Minisztérium KDP-13-1/PALY-2021 kódszámú Kooperatív Doktori Programjának a Nemzeti Kutatási, Fejlesztési és Innovációs Alapból finanszírozott szakmai támogatásával készült.
} 
töltött időnek azonban nagy költségei vannak, amelyek nem csak az anyák jelenlegi anyagi helyzetére vannak hatással, hanem nagyban befolyásolják a jövőbeli munkaerőpiaci elhelyezkedés kilátásait is. Ennek oka, hogy az otthon töltött idő, csökkenti az anyák piaci értékét (pl. tudás elavulása), ami a jövőben kevésbé kívánatos munkavállalóvá teszi őket a foglalkoztatók számára (Mincer - Polachek 1974). A szülést követő munkaerőpiaci szerepvállalás időzítését azonban számos egyéni és társadalmi szintű tényező befolyásolhatja. Jelen tanulmány célja, hogy bemutassa a várandóskori munkavállalási tervek alakulását fél évvel a szülés után, továbbá, hogy meghatározza egyes tényezők mentén hogyan jellemezhetők azok az anyák, akik gyermekük féléves kora előtt munkát vállaltak. Az elemzés során az e csoporthoz tartozó anyákat nevezem korai munkavállalóknak. A következőkben elsőként a rendelkezésre álló szakirodalmak és kutatások mentén részletezem az időzítést befolyásoló egyes tényezőket, majd pedig bemutatom a kisgyermekes anyák munkavállalásáról alkotott közvélemény alakulását Magyarországon, valamint részletezésre kerülnek a hazai munkavállalást támogató családpolitikai intézkedéseket. Ezt követően kerül sor a várandóskori munkavállalási tervek alakulásának nyomon követesére, majd pedig a korai munkavállalók egyes szociodemográfiai és egyéb jellemzőinek bemutatására. A tanulmány végét záró fejezet összegzi a kutatás főbb megállapításit.

Az elemzések a KSH - Népességtudományi Kutatóintézet szervezésében 2018-ban indult, Kohorsz '18 Magyar Születési Kohorszvizsgálat elnevezésü longitudinális, panelkutatás első és második hullámának adataira épülnek. Az első hullámban résztvevő anyák 2018-19 között várandósságuk hetedik hónapjában voltak, a második adatfelvétel során pedig megszületett gyermekük hat hónapos korában keresték fel őket a lekérdezést végző védőnők (Veroszta, 2018). Az adatfelvételi hullámok során a létrejövő adatbázisok, több mint nyolcezer résztvevő válaszait tartalmazzák.

\section{A szülés utáni munkaerôpiaci szerepvállalás idejét befolyásoló tényezők}

A szülést követő munkavállalás folyamatának és sajátosságainak nyomon követésére számos kutatás áll rendelkezésre (McGovern et al. 2000, Drejnovszky 2009, R. Fedor 2015, Makay 2017a). Leitheiser és Veroszta (2021) egy friss tanulmányukban ugyancsak a Kohorsz '18 adatait elemezve arra jutottak, hogy ,[...] önmagában a modernebb férfi-női szerepfelfogás, a nöi domináns foglalkozások, a kedvezőbb jövedelmi szint, a lakóhely bölcsődei ellátottsága, de föként az alacsonyabb, már meglévö és tervezett gyermekszám rövidítik le a munkaeröpiaci visszatérés várandós időszakban tervezett idejét" (Leitheiser - Veroszta 2021: 199). Bár az anyák munkavállalása szempontjából a települések esetében a gyermekellátáshoz való hozzáférés kiemelkedően fontos, - Kapitány (2019) egyik kutatásából kiderül, hogy azon az anyák 93\%-a, akik bölcsödébe tervezik adni gyereküket, munkát is tervez vállalni gyermek hároméves kora elött - önmagában a településtípus is befolyásolhatja a munkaeröpiacra való betagozódást.

Mindezek mellett azonban fontos, hogy bővebben részletezzük az egyes kemény szociodemográfiai tényezők korai munkavállalásra gyakorolt hatásait, úgy, mint az anya kora, iskolai végzettsége, partnerkapcsolati és jövedelmi helyzete, valamint gyermekeinek száma és kora. R. Fedor (2015) egyik kutatásában két almintán (összesen: 427 fö) vizsgálta a legalább egy, maximum hétéves gyermeket nevelő anyák munkaerőpiaci szerepvállalásának 
sajátosságait. Az egyik almintát a már dolgozó anyák képezték a másikat pedig az adatfelvétel pillanatában gyeden/gyesen lévők. Eredményei szerint az egyes korcsoportok közül a 18-20 év közti dolgozó anyák térnek vissza a legnagyobb arányban dolgozni a szülést követő hat hónapon belül, a gyermek 6-12 hónapos kora között pedig megnő a 26-30 év közöttiek, valamint a 30 éven felüliek munkavállalási hajlandósága, amely tovább fokozódik a gyermek egy és kétéves kora között. A szülést követően otthon töltött idő a 21-25 éves korosztály esetében a leghosszabb. R. Fedor iskolai végzettségre vonatkozó eredményei alapján kijelenthető, hogy az egy éves kor előtti munkavállalók aránya bár miden iskolaivégzettségkategóriában igen alacsony, e magatartás mégis nagyobb arányban jellemzi a felsőfokú végzettséggel rendelkezőket. A magasabb iskolai végzettség gyorsító hatását Makay (2017a) és Drejnovszky (2009) eredményei, valamint a KSH (2019) elemzései is megerősítik. A Munkaerőpiaci helyzetkép (KSH 2019) alapján megállapítható, hogy míg a legfeljebb nyolc osztályt végzett 25-49 éves, legalább egy gyermeket nevelő nők 50,3\%-a volt foglalkoztatott 2017-ben, addig ugyan ez az arány a felsőfokú végzettséggel rendelkezők esetében 73,2\%. Makay (2017a) kutatásában a magas iskolai végzettség hatását még kiegészíti azzal, hogy a gyorsító effektus az alacsonyabb iskolai végzettséggel rendelkezőkhöz képest, még inkább nyomon követhető a második gyermek megszületését követően. A partnerkapcsolati státusz hatását tekintve Drejnovszky (2009) kutatásában bár azt tapasztalta, hogy egyedülállókra inkább jellemző a rövidebb otthon töltött idő, mégis hangsúlyozza, hogy nem állapítható meg egyértelműen a partnerkapcsolati helyzet hatása. E kijelentést támasztja alá az is, hogy míg Hofferth és Curtin (2003) kutatásukban negatív kapcsolatot mutattak ki a házasság és a szülést követő munkaerőpiaci szerepvállalás között (a házas anyák hamarabb kezdenek dolgozni a szülést követően), addig R. Fedor és Toldi (2017) valamint McGovern és szerzőtársai (2000) éppen az ellenkezőjét tapasztalták, miszerint inkább az egyedülállókat és az elváltakat jellemzi inkább a hamarabbi munkavállalás. Percheski (2008) tanulmányában továbbá hangsúlyozza, hogy a partnerkapcsolat vizsgálatakor, nem szabad megfeledkeznünk a partner munkaerőpiaci helyzetéről sem, mivel az otthon maradó anyák számára férjük jövedelme egyfajta gazdasági biztonságérzetet nyújthat, amely megnövelheti az otthon töltött idő hosszát. Ezen megállapítást támasztják alá Klerman és Leibowitz (1990) eredményei is, amelyek szerint bár a nők szülést követő munkavállalását a magas iskolai végzetség és a magas egyéni jövedelem meggyorsítja, egy magas jövedelemmel rendelkező férj megléte - és ezáltal a magasabb háztartási jövedelem - azonban lelassítja azt.

Mindezek mellett a nevelt gyermekek számának és korának hatását is fontos figyelembe vennünk az anya munkaerőpiaci részvételének vizsgálatakor. Mind az OECD (2020), mind az Eursotat (2021) mind pedig a magyar munkaerőfelmérések alapján készített Munkaerőpiaci helyzetkép (KSH 2019) adatai alátámasztják, hogy a gyermekszám növekedésével csökken az anyák foglalkoztatási rátája, a gyermek korának elörehaladtával azonban növekszik. Az OECDországokban 2019-ben átlagosan a legalább egy gyermekkel rendelkező anyák 71\%-a volt foglalkoztatott, akik közül 18\% - Magyarország esetében 10\% - dolgozott részmunkaidőben. A 15 és 64 év közötti gyermektelen nők foglalkoztatási rátája ehhez képest 63\%-on áll. Az OECD (2020) elemzései szerint a gyermek kora szerinti foglalkoztatási különbségek Magyarországon, Finnországban, Csehországban, Észtországban, valamint Szlovákiában követhetőek a leginkább nyomon. Míg hazánkban a 0-2 éves korú gyereket nevelő anyák 
csupán 16\%-a dolgozik, 3-5 éves gyermeket nevelők esetében ez az arány 73\%-ra, a 6-14 éves gyermekkel rendelkezőknél pedig 87\%-ra növekszik. Hasonlóan nagy eltérések találhatóak Magyarországon a gyermekszám tekintetében is. Az egy gyermekkel rendelkezö anyák foglalkoztatási rátája, valamit a három vagy több gyermeket nevelő anyák foglalkoztatási rátája között több, mint 25 százalékpontos különbség figyelhető a kevesebb gyermekkel rendelkezők javára. Hasonló eredményeket tapasztalhatunk az Eurostat (2021) eredményei alapján azonban, ha a fő gyermekvállalási korra (20-49) szükítjük a megfigyeléseinket az tapasztalható, hogy a gyermektelenek foglalkoztatási rátája az országok többségében magasabb, mint a legalább egy (6 éven aluli) gyermekkel rendelkezőké. Magyarországon, a 20-49 év közti gyermektelen nők foglalkoztatottsági rátája 85,7\%, az egy gyermekes anyáké 42,9\% a három vagy több gyermekkel rendelkezőké pedig 32,6\%. Érdekes, hogy Magyarország esetében kétgyermekes anyák foglalkoztatási rátája $(48,1 \%)$ nem csak a háromgyerekesét, de az egy gyermekkel rendelkezőkét is meghaladja. A Munkaerőpiaci helyzetkép 2017-re vonatkozó elemzései szerint, a 25-49 év közti háromévnél fiatalabb gyermeket nevelő anyák csupán 15\%-a volt foglalkoztatott, a 14 éves gyermeket nevelő családokban ez az arány azonban $89 \%$.

\section{A magyar közvélemény alakulása a kisgyermekes anyák munkavállalásáról}

Az egyes térségek társadalmainak köreiböl a nök munkavállalása eltérö fogadtatást váltott ki, pedig a nők és az ő csoportjukon belül is az anyák munkavállalásával kapcsolatos uralkodó nézetek, kiemelkedően fontosak lehetnek a gyermekvállalás utáni munkaerőpiaci szerepvállalás szempontjából. Néhány dél-európai konzervatív országban - ahol jellemzően alacsony az anyák foglalkoztatása - mint például Spanyolországban (59,5\%), Görögországban $(52,2 \%)$ és Olaszországban $(55,3 \%)$,,a reprodukciós funkciók, az anyaság előtérbe állításával mind társadalmi szinten (az intézményi hálózat visszafogott fejlesztésével), mind családi szinten (a férfiak otthoni szerepvállalása fontosságának nem kellő hangsúlyozásával) megnehezítik a nők kettős ambíciójának, nevezetesen a karrier és a gyermekvállalás egyidejü megvalósításának realizálását" (Pongrácz - S. Molnár 2011: 192). Mindattól eltekintve, hogy az említett országokban meghatározó szerepe van a katolikus vallásnak, a házasság intézményének és a családi kötelékeknek, mégis a nőkben kialakult konfliktus a gyermekvállalás és a karrierépítés között, valamint az e konfliktus feloldására törekvő politikai intézkedések hiányának eredményeként ezekben a térségekben a születési arányszámok jellemzően alacsonynak mondhatók. (Matysiak - Vignoli 2010, Vignoli 2011, Billari, 2006). Ha azonban a nők kettős szerepének elfogadottsága sem társadalmi, sem kormányzati (családpolitika, családjog) szinten nem ütközik akadályba - mint ahogyan az a skandináv államokban és egyes nyugat-európai országokban (Franciaország, Hollandia) tapasztalható akkor a gyermekvállalási mutatók egyértelműen pozitív irányba mozdulnak el (Pongrácz - S. Molnár 2011). Fontos azonban kihangsúlyozni, hogy a szülést követő otthon töltött idő kérdését illetően a szakértőknek sincs egységes álláspontjuk (R. Fedor - Takács 2013). Herczog (2008) eredményei szerint az első két otthontöltött évnek erősebb pozitív hatása van a gyermek fejlődésére, mint a 3. és 4. otthon töltött évnek, a gyermek egy éves koráig való otthon maradás fontosságát és annak fejlődésre gyakorolt kulcsfontosságú hatását pedig Blaskó (2010) is megerősíti. 
Makay (2017b) tanulmányában az Eurobarometer 2017-es adatait felhasználva azt találta, hogy a nyugat-európai országok jelentősen modernebben ítélik meg a nemi szerepeket, mint a közép- és kelet-európai államok. Azzal a kijelentéssel, hogy „A nő legfontosabb feladata a háztartás és a család ellátása" a svédek $11 \%$-a, a németek pedig $28 \%$-a ért egyet, míg Magyarországon a lakosság 78\%-a, Lengyelországban pedig 77\%-a van ugyanezen a véleményen. Habár az utóbbi időben Magyarországon a társadalmi szerepekről alkotott nézetek modernizációja követhető nyomon, még mindig erőteljesen jelen van azon tradicionális felfogás berögzültsége, amely szerint az anyák akkor járnak el helyesen, ha a szülést követő három évben otthon maradnak gyermekük mellett. E felfogás kialakulásához jelentős mértékben hozzájárult az 1967-ben bevezetett gyermekgondozási segély (gyes) és a nem sokkal utána, 1985-ben életre hívott gyermekgondozási díj (gyed) intézménye, amelyek az akkori munkaerőpiaci túlkínálatot kívánták enyhíteni, továbbá a születésszám csökkenését próbálták megállítani azzal, hogy bizonyos mértékü anyagi támogatás biztosítása mellett a szülést követően otthon tartsák a nőket. A létrejött anyasági támogatások következtében az akkori szocialista munkafelfogásnak (teljes foglalkoztatottság) némileg ellentmondva, egy társadalmilag is elfogadott szereppé alakult át a háztartást vezető, gyermekével otthonmardó anya képe (Blaskó 2005, 2011a, Pongrácz - S. Molnár 2011).

A KSH Népességtudományi Kutatóintézet által 2001-ben indított Életünk Fordulópontjai longitudinális panelkutatás adatai alapján is jól látszik a szerepfelfogás modernebb irányba való eltolódása, bár a többség esetében még mindig a tradicionálisabb értékek preferálása dominál. A kutatás második, negyedik és ötödik hullámában a válaszadók egy ötfokú skálán jelölhették be azon kijelentéssel való egyetértésüket, miszerint „Három éves kor elött a gyermekek megsínylik, ha az anyjuk eljár dolgozni”.

1. táblázat: Három éves kor előtt a gyermekek megsínylik, ha az anyjuk eljár dolgozni

\begin{tabular}{cccc}
\hline Válasz & $\mathbf{2 0 0 4 / 2 0 0 5}$ & $\mathbf{2 0 1 2 / 2 0 1 3}$ & $\mathbf{2 0 1 6 / 2 0 1 7}$ \\
\hline $\begin{array}{c}\text { Egyáltalán nem ért } \\
\text { egyet }\end{array}$ & $3,7 \%$ & $5,6 \%$ & $8,6 \%$ \\
\hline Nem ért egyet & $3,3 \%$ & $6,1 \%$ & $7,1 \%$ \\
\hline Is-is & $8 \%$ & $14,4 \%$ & $16,5 \%$ \\
\hline Egyetért & $12,7 \%$ & $17,8 \%$ & $17,5 \%$ \\
\hline Teljesen egyetért & $72,2 \%$ & $56,1 \%$ & $50,3 \%$ \\
\hline Összesen & $100 \%$ & $100 \%$ & $100 \%$
\end{tabular}

Megjegyzés: Az esetszám azokra a válaszadókra lett leszürve (nemtől függetlenül), akik mind a három hullámban megválaszolták a szóban forgó kérdést. Életkor: 37-94. $\mathrm{n}=6230$. Forrás: Életünk Fordulópontjai, 2. 4. 5. hullám, KSH NKI, a szerző számítása.

Míg a 2000-es évek közepén a megkérdezettek 72,2\%-a értett teljesen egyet azzal, hogy a gyermekeknek az a jó, ha az anyák a munkavállalást mellőzve otthon maradnak, addig ez az arány 2017-ben 50,3\%-ra csökkent. Ezzel párhuzamosan 3,7\%-ról 8,6\%-ra nőtt a tradicionális 
nézeteket szigorúan ellenzők aránya is, bár ez a változás nem annyira drasztikus, mint azok esetében, akik határozottan elutasítják az anyák szülést követő három éven belüli munkavállalását.

A hagyományos szerepek máig fellelhető berögzültsége támasztható alá a Kohorsz '18 adatfelvétel eredményei alapján is, amelyben a várandósságuk hetedik hónapjában lévő résztvevőktől többek között azt is megkérdezték: „Mit gondol, mi a jó a babának, meddig kellene otthon maradnia vele az anyának a munkába való visszatérés előtt?” Bár a következő ábra értelmezésekor szem előtt kell tartanunk, hogy a megkérdezettek között kizárólag nők szerepelnek, akinek átlagos életkora 30 év volt, mégis jól látszik a hagyományos szerepekhez köthető nézetek elterjedtsége e csoporton belül is.

\section{1. ábra: Mit gondol, mi a jó a babának, meddig kellene otthon maradnia vele az anyának a munkába való visszatérés előtt?}

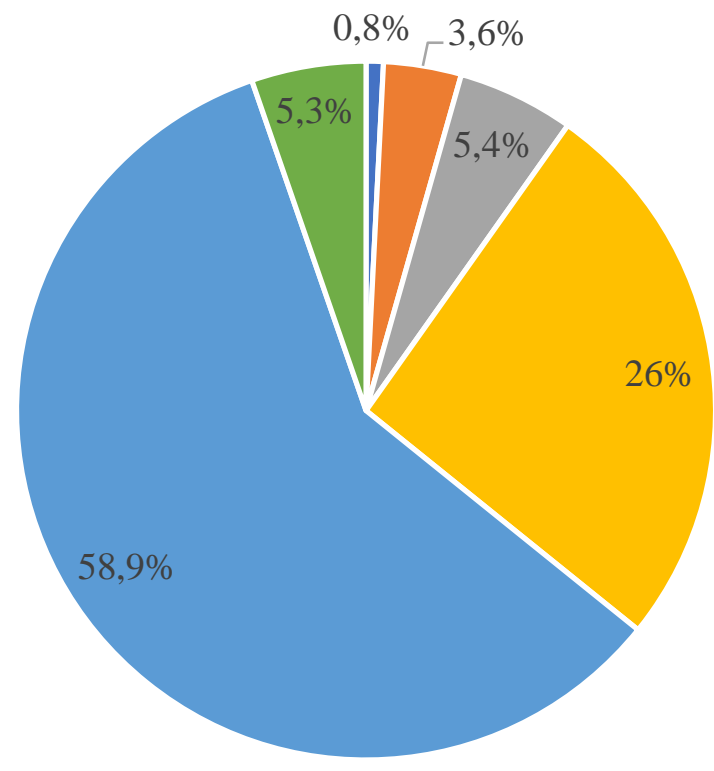

- legalább a baba féléves koráig

- legalább a baba egyéves koráig

- legalább a baba másféléves koráig

- legalább a baba kétéves koráig

- a baba hároméves koráig

- a baba hároméves korán túl, akár állandó jelleggel is

Forrás: Kohorsz '18 Magyar Születési Kohorszvizsgálat, várandós és féléves kutatási adatbázis, KSH NKI, n=818.

Míg az anyák döntő többsége (58,9\%), úgy gondolta, hogy az a legjobb gyermeke számára, ha legalább hároméves koráig vele marad otthon, mellözve a munkavállalást, addig valamivel több, mint a negyedük (26\%) akár már gyermekük kétéves kora körül munkát vállalna, 3,6\%-uk pedig azt is elképzelhetőnek tartja, hogy akár éves kora környékén. A válaszadók csupán elenyésző hányada $(0,8 \%)$ vélekedett úgy, hogy akár már a szülést követő fél éven belül munkát vállalna. Mindezek alapján mégis úgy látszik, hogy fokozatosan és meglehetősen lassú ütemben, de a magyar társadalomban egyre szélesebb körében vált elfogadottá a nők - gyermekük hároméves kora előtti - munkaerőpiaci szerepvállalása (lásd 1. táblázat és 2. ábra).

\section{Kisgyermekes anyák munkavállalását támogató családpolitikai intézkedések}


Bár a magyar anyák többsége az uralkodó társadalmi szerepekhez köthető attitüdöknek megfelelően jellemzően csak gyermekük hároméves kora után vállal munkát (Drejnovszky 2009), a lassan változó szerepfelfogások mellett elengedhetetlen az egyre bővülö családpolitikai intézkedéseket figyelembevétele, amelyekkel mindjobban törekednek a kisgyermekes anyák munkavállalásának megkönnyítésére. A magyar családpolitika célja kettős; egyfelől a kedvezőtlen demográfiai trendeket (népességfogyás) kívánja megállítani és lehetőleg az ellenkezőjére fordítani, másfelől pedig, mivel „[...] minden család számít, egyszerre kell a legszegényebb, már lakhatásában is veszélyeztetett családoknak segiteni, a lecsúszóban lévők romló helyzetét kezelni, és a középrétegek elszegényedését megállitani" (Nemzeti Együttmüködés Programja, 4.2 pont). A családtámogatások legnagyobb hányadát (nagyjából egyharmadát) a pénzbeli juttatások teszik ki, ezt követik a családokat segítő szolgáltatások (pl. óvodai, bölcsődei szolgáltatás, ingyenes étkezés, tankönyvellátás stb.) majd pedig az érvényesített adó- és járulékkedvezmények, valamint az otthonteremtési támogatások, továbbá a nők számára elérhető kedvezményes - korhatár alatti - nyugellátás kiadásai. A támogatásokra fordított költségvetési forrás 2010 és 2018 között 960,2 milliárd Ft-ról 1929,1 milliárd Ft-ra nőtt, 2020-ra pedig megközelítőleg 2228 milliárd forintot irányzott elő az Országgyülés. 2021-ben a kormány 2295 milliárd Ft-ból finanszírozza ezeket az intézkedéseket. A családtámogatások GDP-ben kifejezett összegében azonban érdekes módon 2017 óta csökkenés figyelhető meg. Míg 2017-ben az intézkedésekre fordított összeg a GDP 4,7\%-át tette ki Magyarországon, addig ez a szám 2018-ra 4,6\%-ra, 2019-re pedig 4,4\%-ra csökkent. Ennek oka egyfelől a GDP általános növekedésében, valamint a születésszámok csökkenésében keresendő, amely következtében egyes állátások esetében csökken az igénybevételre jogosultak száma (Nagy et al. 2021).

Bár a fentebb már említett - anyagi támogatások közé tartozó - gyes intézményének kialakításakor éppen a nők munkaerőpiaci kiszorítása volt az egyik cél, a gyed esetében azonban az otthon maradó nők jövedelmének emelése. Mindezek mellett, a CSED (csecsemőgondozási díj) 24 hét fizetett szabadságot biztosít az anyák számára - abban az eseteben, ha az anya a szülést megelőző két évben, 365 napon biztosított volt - amelyből legfeljebb négy hetet vehetnek igénybe a szülés napja előtt. Amellett, hogy a gazdaság megfelelő működéséhez egyre nagyobb szükség van a nők foglalkoztatottságának növelésére, mára a kormányzat azt is felismerte, hogy a születés számok a nők otthon maradása mellett sem növekednek kellő mértékben, így egyre nagyobb hangsúlyt kapott a család és a munkaerőpiaci szerepvállalás közti egyensúly kialakításának elősegítése. Ennek megfelelően a kormány lazítani kezdett a gyermekek után igénybevehető támogatások kritériumain, továbbá 2012-ben, egy módosítás keretében a Munka Törvénykönyvében - bár eltörölték a szülők felmondási védelemét - elöírták a munkaadók számára, hogy kötelesek minden, a harmadik évét még be nem töltött gyermeket nevelő munkavállaló számára részmunkaidős foglalkoztatást biztosítani, ha a munkavállaló ezt igényli (Makay 2015, Makó 2018). Mindemelett a támogatások igénybevevőinek jogilag biztosítottá tették, hogy a jogosultság lejártát követően ugyanarra a munkahelyre térhessenek vissza (Spéder et al. 2019). A reform következményeként 2014-től a gyes és gyed mellett is lehetőség nyílt a teljesidőben történő munkavállalásra (un. gyed extra reform részeként), 2020-ban pedig bevezették a négy- vagy többgyerekes anyák személyi jövedelemadó-mentességét, valamint a nagyszülői gyedet, amelyet a még nem nyugdíjas, 
munkaerőpiacon aktív nagyszülö vehet igénybe unokája kétéves koráig. Az egyes anyagi támogatásokon túl azonban a nappali gyermekfelügyeletet állátó intézményi kapacitás bővítése is szükséges az anyák foglalkoztatási mutatóinak javításához. Ennek érdekében a kormány 2019-ben kiterjesztette a bölcsődefejlesztési programot, amely keretében 2022-re a 2018-ban meglévő 48 ezer férőhelyet 70 ezerre kívánják bővíteni. Az intézkedés további elemeként, a munkába álló szülők havi rendszerességü támogatást igényelhetnek a családi vagy munkahelyi bölcsődék szolgáltatásának igénybevételhez (Makay 2017b, Nagy et al. 2021).

\section{Várandóskori munkavállalási tervek alakulása félévvel a szülés után}

A kutatásban résztvevő anyák 3,6\%-a $(\mathrm{n}=281)$ már dolgozott gyermeke féléves korában 7,4\%a tervezi, de csak a következő gyermeke megszületését követően, 9,4\% ugyan tervezi a munkavállalást, de még nem tudta megmondani mikor, $6,2 \%$ pedig egyáltalán nem tervezi, hogy dolgozzon. A várandóskori terveket megfigyelve kijelenthető, hogy a bizonytalanok aránya némileg lecsökkent - várandóskorban a válaszadók 10\%-a tartozott ebbe a kategóriába - a munkavállalást nem tervezők aránya azonban megnőtt, a várandóskori 5,4\%-hoz képest. Azok körében, akik gyermekük kora szempontjából pontos tervekkel rendelkeztek a szülést követő munkavállalás idejéről megállapítható, hogy a várandóskori tervekhez képest - amikor is az anyák, átlagosan gyermekük 29,5 hónapos korára datálták a munkavállalást - a gyermek féléves korában jelezett átlagos munkavállalási szándék ideje (30,3 hónapos kor) közel egy hónappal növekedett.

\section{2. táblázat: Várandóskori munkavállalási tervek alakulása félévvel a szülés után}

\begin{tabular}{ccccccc}
\hline $\begin{array}{c}\text { Munkavállalás } \\
\text { tervezett ideje } \\
\text { várandós korban }\end{array}$ & \multicolumn{6}{c}{ Munkavállalás tervezett ideje a gyermek fél éves korában } \\
\cline { 2 - 7 } & $\begin{array}{c}\text { Már most is } \\
\text { dolgozik }\end{array}$ & $\begin{array}{c}7 \text { hónap - } \\
1 \text { év }\end{array}$ & $1-2$ év & $2-3$ év & 3 év - & Össz. \\
\hline $\mathbf{0}$ - $\mathbf{6}$ hónap (n=186) & $\mathbf{5 0 \%}$ & $11,8 \%$ & $19,4 \%$ & $17,2 \%$ & $1,6 \%$ & $100 \%$ \\
\hline $\mathbf{7}$ hónap - 1 év (n=240) & $11,7 \%$ & $\mathbf{3 1 , 7 \%}$ & $39,2 \%$ & $14,6 \%$ & $2,9 \%$ & $100 \%$ \\
\hline $\mathbf{1 - 2}$ év (n=1855) & $2,4 \%$ & $4,2 \%$ & $\mathbf{6 3 , 2 \%}$ & $27,6 \%$ & $2,6 \%$ & $100 \%$ \\
\hline $\mathbf{2 - 3}$ év (n=2531) & $2 \%$ & $1,6 \%$ & $15,4 \%$ & $\mathbf{6 9 , 3}$ & $11,7 \%$ & $100 \%$ \\
\hline $\mathbf{3}$ év - (n=253) & $2 \%$ & $1,6 \%$ & $5,1 \%$ & $49,4 \%$ & $\mathbf{4 1 , 9 \%}$ & $100 \%$ \\
\hline
\end{tabular}

Forrás: Kohorsz '18 Magyar Születési Kohorszvizsgálat, várandós és féléves kutatási adatbázis, KSH NKI, $\mathrm{n}=5056$, a szerző számítása. Szignifikancia $=<0,000$ Cramer’s V=0,396.

A kereszttábla eredményei alapján megállapítható, hogy a várandósságuk hetedik hónapjában korai munkavállalást tervezők 50\%-a váltotta valóra előzetes elképzeléseit. 19,4\% esetében a tervek a gyermek 1-2 éves kora közé tolódtak, 17,2\% esetében pedig a gyermek 2-3 éves kora közé. Megfigyelhető azonban, hogy a várandóskorban gyermekük 7 hónapos és 1 éves kora közötti munkavállalást tervezők 11,7\%-a már dolgozott gyermeke féléves korában, a szülést követő 2-3 év között munkavállalást tervezők aránya esetében pedig a fél éven belüli aktív dolgozók aránya 2,4\%. Kis mértékben, de a gyermekük 2-3 éves kora közötti (2\%), illetve a 3 éves kori utáni (2\%) munkavállalási szándékkal rendelkezők esetében is nyomon követhető 
a munkavállalás elöbbre hozatala a gyermek féléves korában. További nagyobb mértékü előbbre tolódás figyelhető meg a várandós tervek esetében a gyermek 2-3 éves kora közötti, valamint a 3 éves kor utánra vonatkozó előzetes munkavállalási terveket illetően. Míg az előbbi 15,4\%-ban a féléves adatfelvételkor a gyermek 1-2 éves korára csúszik vissza, addig az utóbbi esetében még ennél is nagyobb, 49,4\%-os előbbre tolódás rajzolódik ki a szülést követő 2-3 év közötti munkavállalás javára. A kitolódás leginkább a gyermek 7 hónapos és 1 éves kora közé tervezett munkavállalás esetében követhető nyomon, ahol az anyák 39,2\%-a a gyermek féléves korában már a gyermek 1-2 éves kora közé halasztaná a munkaerőpiaci szerepvállalást, valamint a gyermek 1-2 éves kora közötti előzetes terveket esetében, amelyeket illetően az anyák 27,6\%-a inkább a gyermek 2-3 éves kora között vállalna munkát.

Mindezek alapján a korai munkavállalókat terveik és azok kimenetele szerint négy kategóriába oszthatjuk. Az elsőt azok alkotják, akik a várandóskori szándékaiknak megfelelően gyermekük féléves korában már dolgoztak, a másodikba azonban azok kerülnek, akik korábbi elképzeléseik ellenére elhalasztották a munkavállalási szándékaikat. A harmadik csoportot azok képzik, akik bár várandósságuk hetedik hónapjában még nem terveztek gyermekük féléves korában munkát vállalni, a féléves adatfelvételkor azonban már még is dolgoztak, a negyedik legnagyobb $(93,8 \%)$ csoportba pedig azok kerülnek, akik nem terveztek és nem is vállaltak munkát gyermekük féléves korában.

\section{2. ábra: Korai munkavállalók kategorizálása}

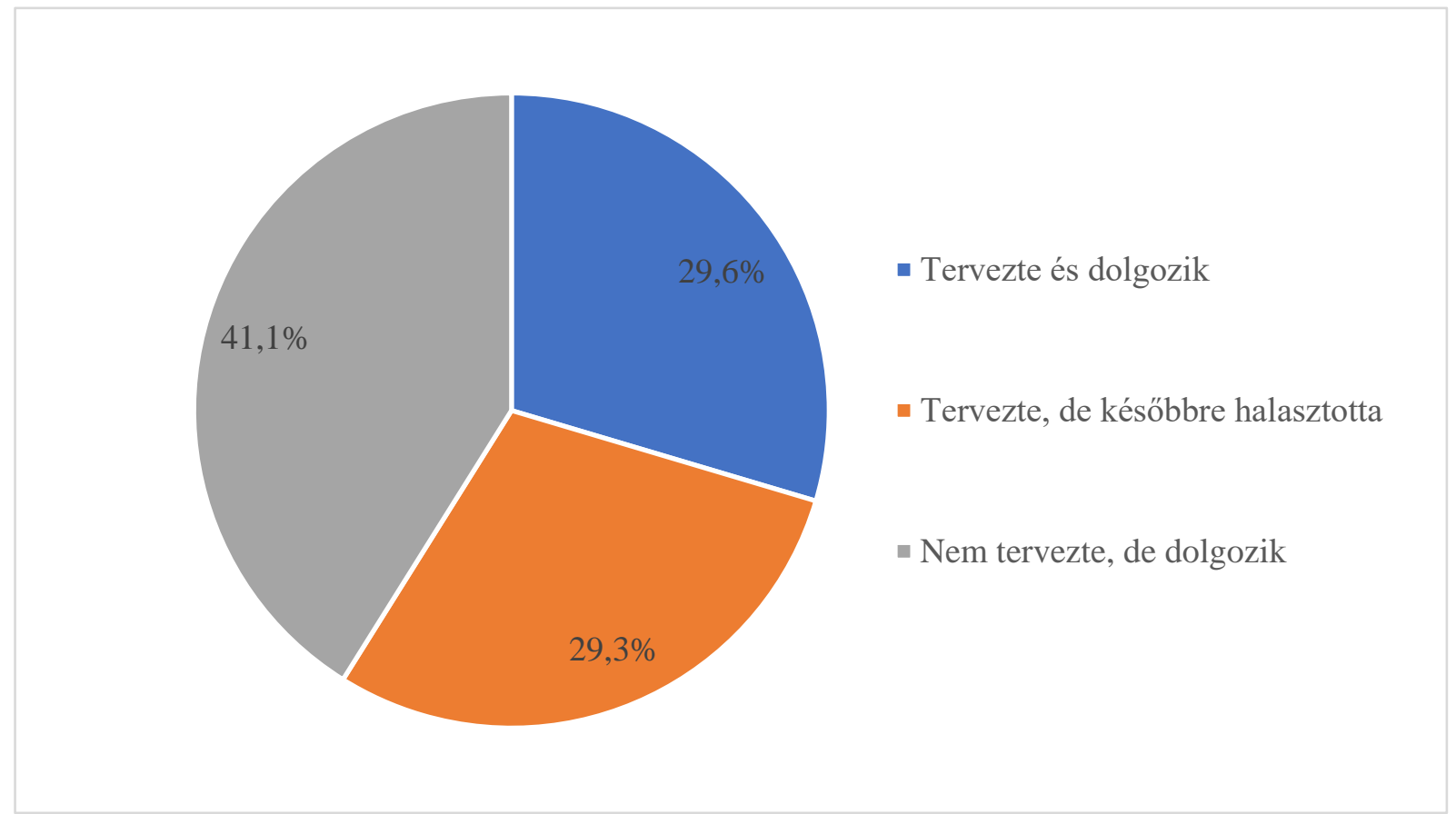

Forrás: Kohorsz '18 Magyar Születési Kohorszvizsgálat, várandós és féléves kutatási adatbázis, KSH NKI, n=316, a szerző számítása.

Ha a korai munkavállalás szempontjából releváns csoportokat vesszük figyelembe és elhagyjuk a negyedik kategóriát jól látszik, hogy a legtöbben (41,1\%) azok az anyák vannak, akik bár várandóságuk alatt nem terveztek a szülést követő fél éven belül munkát vállalni, ennek ellenére még is dolgoznak. 


\section{A korai munkavállalók főbb szociodemográfiai és egyéb jellemzői}

Kiszürve a pontos munkavállalási tervekkel nem rendelkezőket, az anyák 4,7\%-a tartozik a korai munkavállalók csoportjába, 95,3\%-uk pedig egylöre még csak tervezte a munkavállalást, gyermeke valamilyen idős korában.

\section{3. táblázat: Korai munkavállalók szociodemográfiai jellemzői}

\begin{tabular}{|c|c|c|c|c|c|c|c|}
\hline \multicolumn{8}{|c|}{ Egyéni jövedelem (nettó ezer/hó, n=238) } \\
\hline \multicolumn{2}{|c|}{$>100$} & \multicolumn{2}{|c|}{$101-200$} & \multicolumn{2}{|c|}{$201-300$} & $301-400$ & $400<$ \\
\hline \multicolumn{2}{|c|}{$31,1 \%$} & \multicolumn{2}{|c|}{$39,5 \%$} & \multicolumn{2}{|c|}{$16 \%$} & $6,3 \%$ & $7,1 \%$ \\
\hline \multicolumn{4}{|c|}{$\begin{array}{l}\text { Hányadik gyermeke a most féléves gyerek } \\
\qquad(\mathrm{n}=265)\end{array}$} & \multicolumn{4}{|c|}{ Iskolai végzettség ( $\mathrm{n}=\mathbf{2 6 5})$} \\
\hline 1. & 2. & 3. & $4+$ & $\begin{array}{l}\text { max. } 8 \\
\text { osztály }\end{array}$ & $\begin{array}{l}\text { szakmunk } \\
\text { ás }\end{array}$ & $\begin{array}{c}\text { középfok } \\
\text { ú }\end{array}$ & felsőfokú \\
\hline $45,7 \%$ & $36,2 \%$ & $14,7 \%$ & $3,4 \%$ & $7,9 \%$ & $10,2 \%$ & $35,8 \%$ & $46 \%$ \\
\hline \multicolumn{4}{|c|}{ Párkapcsolat (n=264) } & \multicolumn{4}{|c|}{ Korcsoport $(\mathrm{n}=\mathbf{2 6 3})$} \\
\hline $\begin{array}{l}\text { házastár } \\
\text { sával él } \\
\text { együtt }\end{array}$ & $\begin{array}{c}\text { élettársáv } \\
\text { al él } \\
\text { együtt }\end{array}$ & \multicolumn{2}{|c|}{$\begin{array}{c}\text { partnere van, de nem } \\
\text { él vele együtt/nincs } \\
\text { partnere }\end{array}$} & $15-25$ év & 26-35 év & \multicolumn{2}{|c|}{$36-45$ év } \\
\hline $56,8 \%$ & $37,1 \%$ & \multicolumn{2}{|c|}{$6 \%$} & $12,2 \%$ & $57,4 \%$ & \multicolumn{2}{|c|}{$30,4 \%$} \\
\hline
\end{tabular}

Forrás: Kohorsz ’18 Magyar Születési Kohorszvizsgálat, várandós és féléves kutatási adatbázis, KSH NKI, a szerző számítása.

A korai munkavállalók egyes szocidemográfiai jellemzői alapján elmondható, hogy nagyobb arányban vállaltak munkát gyermekük féléves korában azok az anyák, akiknek egy gyermeke van (45,7\%), akik magasabb iskolai végzettséggel rendelkeznek (46\%) valamint akik házastársukkal élnek együtt (56,8\%). Az egyes korcsoportokat megfigyelve kijelenthetö, hogy a szülést követő fél éven belüli munkavállalás leginkább a 26 és 35 éves kor közti anyákra jellemző $(57,4 \%)$, a várandóskori jövedelem vonatkozásában pedig megállapítható, hogy legnagyobb arányban (39,5\%) azok mentek vissza dolgozni gyermekük hat hónapos korában, akik egyéni jövedelme 100 és 200 ezer forint közé esett havonta.

Az egyéni jövedelmi jellemzőket érdemes megfigyelnünk a korai munkavállalók fentebb már bemutatott három kategóriája szerint is.

Jól látszik, hogy a korai munkavállalást tervezők három csoportján belül is az anyák többsége maximum 200 ezer forint egyéni jövedelemmel rendelkezik. Bár a terveiket elhalasztók és a terveiket előbbre hozók között nem tapasztalható nagy különbség, mégis a legalacsonyabb jövedelmi kategóriában valamivel magasabb arányban fordulnak elő azok az anyák (40,8\%), akik nem terveztek munkát vállaláni gyermekük féléves koráig, mégis már aktívan dolgoznak ebben az időszakban. Ez alapján arra gondolhatunk, hogy a rosszabb anyagi helyzetben lévő anyák körében gyakrabban fordul elő, hogy a korábbi terveikkel ellentétben 
előbbre hozzák a munkavállalást. A háztartási jövedelmi jellemzők alapján azonban kijelenthető, hogy az anyák legnagyobb hányada, mindhárom kategória esetében a legmagasabb jövedelmi csoporthoz tartozik. Azon anyák 43,2\%-a, akik már várandósságuk hetedik hónapjában is gyermekük féléves korára tervezték a munkavállalást több mint 400 ezer forint háztartási jövedelemmel rendelkezik, ugyan ez az arány a halasztók esetében $36,5 \%$, a terveiket előbbre hozók esetében pedig 35,5\%. Ez alapján inkább arra következtethetünk, hogy a magas háztartási jövedelemmel rendelkezők esetében a magas jövedelem megtartása egyfajta motiváló erővel bír a korai munkavállalás szempontjából.

\section{3. ábra: Korai munkavállalók kategóriái jövedelmicsoportok szerint}

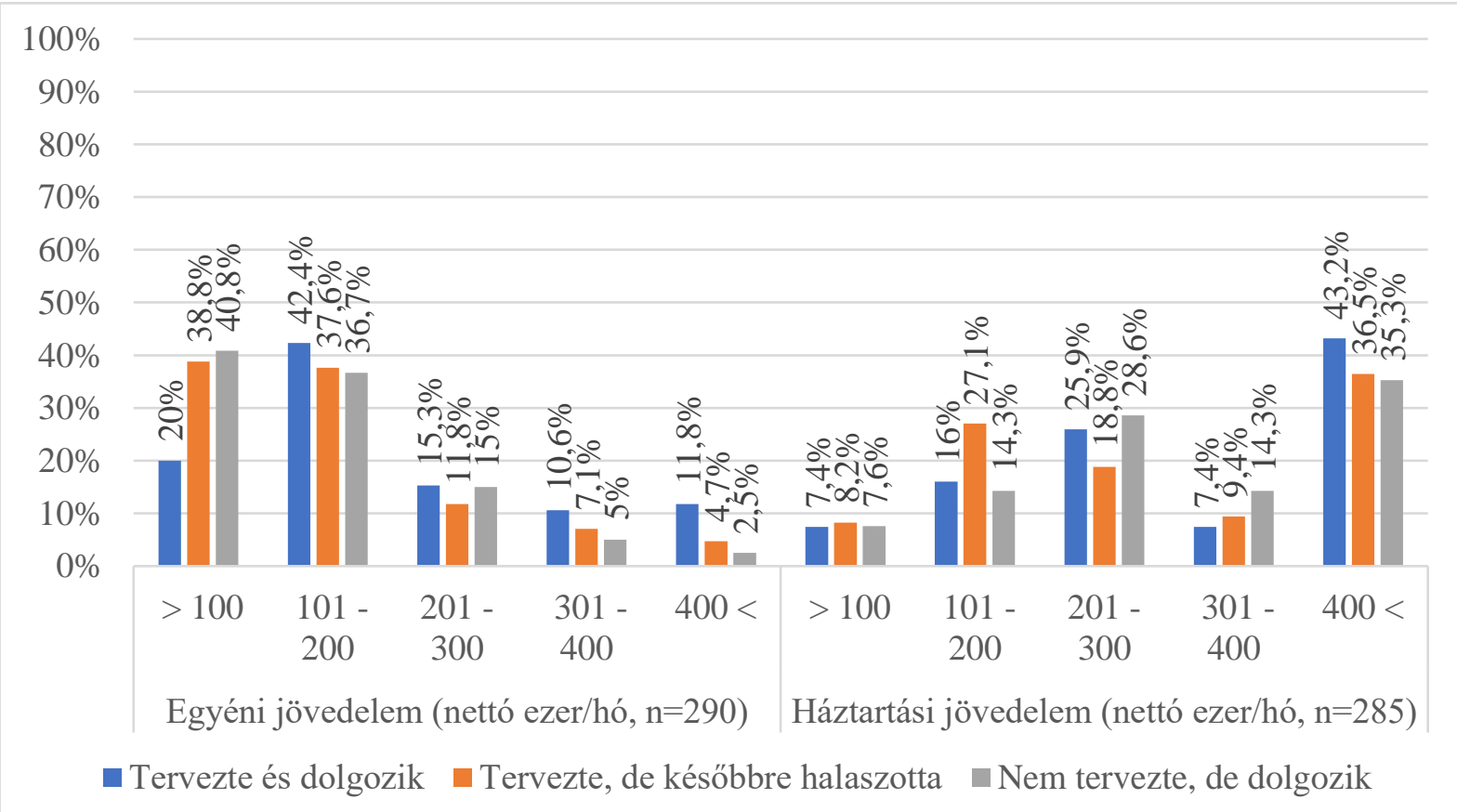

Forrás: Kohorsz ’18 Magyar Születési Kohorszvizsgálat, féléves kutatási adatbázis, KSH NKI, a szerző számítása.

$\mathrm{Az}$ egyes szociodemográfiai jellemzők mellett fontos néhány további, korai munkavállalással kapcsolatos tényezőt is megvizsgálni. Ilyen tényezők a munkavállalás helyszíne, a munkaidő, a korábbi munkaerőpiaci tapasztalat, a munkaviszony, valamint az egyes szubjektív tényezők. A gyermekük féléves korában már dolgozó anyák többsége $(75,8 \%)$ a szülést megelőző munkahelyre tért vissza dolgozni változatlan munkakörben, beosztásban, 18,7\%-uk azonban új munkahelyen kezdett dolgozni. A korai munkavállalók 5,5\%-a bár korábbi munkahelyére ment vissza, más munkakörben vagy más beosztásban kapott munkát. A szülést megelőző munkahelyre változatlan munkakörben, beosztásban visszatért, gyermekük féléves korában már aktívan dolgozó szülőkről a várandóskori adatok alapján továbbá megállapítható, hogy többségük (73\%) teljes munkaidőben dolgozik (azaz heti 40 órában), míg csupán $27 \%$-uk vállalt munkát részmunkaidőben. A korábbi munkaerőpiaci tapasztalatot megfigyelve kijelenthető, hogy a korai munkavállalók 52,6\%-a még várandóssága hetedik hónapjában is aktívan dolgozott, azok körében pedig, akik terveiknek megfelelően a gyermekvállalást követő fél éven belül munkát vállaltak, az anyák $72 \%$-a volt aktív még várandósságának ezen késői szakaszában is. A gyermeke féléves korában még nem dolgozó anyák 56,8\%-a bár rendelkezett meglévő munkaviszonnyal, várandósságának 7 . hónapjában azonban már nem dolgozott. Ugyanez az arány a korai munkavállalók esetében 34,2\%. A szülés 
után hat hónappal már aktívan dolgozó anyák csupán 2,6\%-ának nem volt még soha fizetett munkája, ugyan ez az arány több mint a duplája volt (5,9\%) a gyermekük féléves korában még nem dolgozó anyák esetében. A várandóskori foglalkozási adatokat megfigyelve kijelenthetö, hogy mind a korai munkavállalók, mind pedig a munkavállalást gyermekük idősebb korában tervezők többsége alkalmazottként dolgozik. Érdekes azonban, hogy míg a szülést megelőző munkahelyre, változatlan beosztásban vagy munkakörben visszatérök 44,4\%-a önéllóként vagy vállalkozóként dolgozott, addig a munkavállalást a későbbiekben tervezők esetében ez az arány $4,7 \%$.

\section{4. ábra: Korai munkavállalást befolyásoló szubjektív tényezők megítélése}

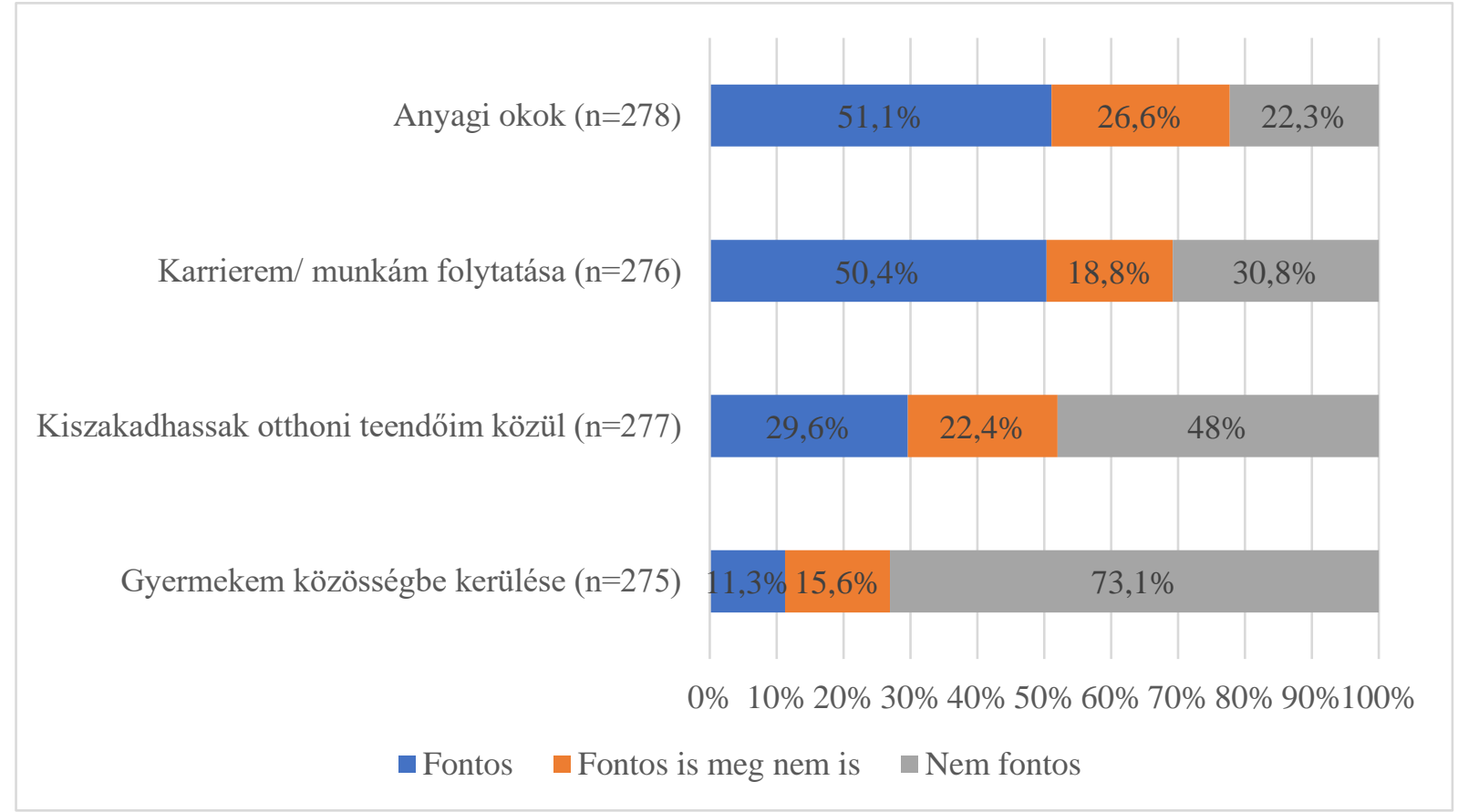

Forrás: Kohorsz '18 Magyar Születési Kohorszvizsgálat, féléves kutatási adatbázis, KSH NKI.

A felmérés során fontos szempont volt a munkavállalás melletti döntés mögött álló egyes szubjektív tényezők feltárása is. A válaszadók egy ötfokú skálán - ahol az 1-es jelentette, azt, hogy egyáltalán nem fontos, az 5-ös pedig, hogy nagyon fontos - jelölhették be, hogy a szülést követően az egyes tényezők milyen mértékben játszottak szerepet a korai munkavállalásban. A munkaerőpiaci szerepvállalás egyes szubjektív tényezőit megfigyelve megállapítható, hogy a korai munkavállalás melletti döntésben az anyagi okokon túl leginkább az anya karrierjének folytatása jelent meg az anyák körében, mint fontos szempont. Az otthoni teendők közül való kiszakadás, valamint a gyermek közösségébe kerülése kevésbé fontos tényezőknek bizonyultak.

\section{Összegzés}

Jelen tanulmány célja az volt, hogy nyomon kövesse a várandóskori munkavállalási tervek alakulását félévvel a szülést követően, illetve, hogy bemutassa a már aktívan foglalkoztatott anyák, korai munkavállalóknak elnevezett csoportja, hogyan jellemezhető az egyes szociodemográfiai és egyéb tényezők mentén. Első lépésként rendelkezésre álló bőséges szakirodalom alapján részleteztem, hogy egyes tényezők miképpen befolyásolhatják a szülést követő munkaerőpiaci szerepvállalás idejét, majd pedig röviden áttekintettem a kisgyermekes 
anyák munkavállalásáról alkotott nézetek alakulását Magyarországon, valamint a vonatkozó családpolitikai intézkedéseket. Bár a Kohorsz '18 adataiból az látszik, hogy az anyák több, mint egy negyede elképzelhetőnek tartja, hogy már gyermeke kétéves kora előtt munkát vállaljon, a többség (58,9\%) még mindig szívesebben maradna gyermeke mellett, annak hároméves koráig. A tradicionális szerepfelfogás elterjedtségét támasztja alá a korai munkavállalók alacsony aránya is, bár számos családpolitikai intézkedéssel próbálják könnyebbé tenni az anyák számára szülést követőn munkavállalást, valamint a munka és a család közötti egyensúly fenntartását.

A tanulmány következő részében, összehasonlítva a munkaerőpiaci szerepvállalás várandóskori tervezett idejét a fél évvel későbbi helyzettel láthatóvá vált, hogy - bár az anyák csupán töredéke vállal munkát gyermeke féléves koráig - azok a nők, akik várandósságuk hetedik hónapjában úgy tervezték, hogy a szülést követő hat hónapon belül dolgozni kezdenek, 50\%-ban valóra váltották szándékaikat. A tervek megvalósulása alapján három kategóriába soroltam az anyákat (tervezte és dolgozik; tervezte, de későbbre halasztotta; nem tervezte, de dolgozik), amelyek közül az anyák többsége $(41,1 \%)$ a nem tervezte, de dolgozik csoporthoz tartozik. A munkavállalás időzítésére vonatkozó tervek alapján úgy látszik, hogy a várandóskori átlagos elképzelésekhez képest, közel egy hónapot toldott ki a tervezett idő, félévvel a szülés után.

A korai munkavállalók szociodemográfiai jellemzőiről megállapítható, hogy többségüknek egy gyermeke van, magas iskolai végzettséggel rendelkezik továbbá házastársával él együtt. Az anyagi helyzet vonatkozásában megállapítottam, hogy a gyermekük féléves korában már dolgozó anyák közel egyharmada kevesebb, mint 100 ezer forint egyéni jövedelemmel rendelkezik. Mindezek mellett a munkavállalás jellemzőivel kapcsolatban kijelenthető, hogy a gyermekük hat hónapos korában már dolgozó anyák többsége (73\%), teljes munkaidőben dolgozik, többségében pedig a szülést megelőző munkahelyre tértek vissza. Elemzésem utolsó pontjaként néhány szubjektív, munkavállalást befolyásoló tényezőt mutattam be, amelyek alapján kijelenthető, hogy a korai munkavállalók számára leginkább az anyagi okok és a karrier folytatása jelent meg fontos szempontként.

Bár jelen tanulmány deskriptív jellege egy stabil alapot jelenthet az elkövetkezendő témába vágó kutatásoknak, a jövőben mégis érdemes akár többváltozós modellek segítségével is megvizsgálni a szülést követő munkavállalást meghatározó egyes tényezőket, kibővítve a háztartáson belüli munkamegosztás mintázataival, az érzékelt munkaerőpiaci diszkrimináció jelenségével, illetve az anyák számára elérhető gyermekfelügyelet részleteinek megfigyelésével. A téma mélyebb feltárást segítik elő a Kohorsz '18 további, jelenleg is zajló hullámai, amelyekben továbbra is fontos szerep jut az anyai munkavállalás jellemzőinek feltérképezésére.

\section{Irodalom}

Bácsné Bába Éva (2014): Kisgyermekes anyák a munkaerőpiacon - pro és contra. TAYLOR, 6(1-2): 250-259.

Billari, Francesco C. (2006): Between policy-maker awareness and policy responses: lowestlow fertility in Italy. EntreNous, 63: 22-23. 
Blaskó Zsuzsa (2005): Dolgozzanak-e a nők? A magyar lakosság nemi szerepekkel kapcsolatos véleményének változásai 1988, 1994, 2002. Demográfia, 48(2-3): 159-186.

Blaskó Zsuzsa (2010): Meddig maradjon otthon az anya? A gyermekfejlödés szempontjai. Kutatási tapasztalatok és társadalompolitikai következtetések. Esély, 21(3): 89-116.

Blaskó Zsuzsa (2011a): Három évig a gyermek mellett - de nem mindenáron. A közvélemény a kisgyermekes anyák munkába állasáról. Demográfia, 54(1): 23-44.

Drejnovszky Zsófia (2009): A szülési szabadság hosszának vizsgálata az első gyermek vállalását követően. Szociológiai Szemle, 2009(3): 116-146.

Eurostat (2021): Employment rate of adults by sex, age groups, educational attainment level, number of children and age of youngest child (\%). Elérhetö: http://appsso.eurostat.ec.europa.eu/nui/submitViewTableAction.do 2021.05.03)

Herczog Mária (2008): A kora gyermekkori fejlődés elősegítése. In Fazekas Károly - Köllő János - Varga Júlia (szerk.): Zöld könyv a magyar közoktatás megújításáért. Budapest: Oktatás és Gyermekesély Kerekasztal, Magyarország Holnap Ecostat, 33-52.

Hofferth, S. L. - Curtin, S. C. (2006): Parental leave statutes and maternal return to work after childbirth in the United States. Work and Occupations, 33(1): 73-105.

Kapitány Balázs (2019): Bölcsődéztetési tervek Magyarországon. Gyermeknevelés, 8(2): 5573.

Klerman, Jacob Alex - Leibowitz, Arleen (1990). Child care and women's return to work after childbirth. American Economic Review, 80(2): 284-288.

Koncz Katalin (2004): A nők munkaerőpiaci helyzete az ezredfordulón Magyarországon. Statisztikai Szemle, 82(12): 1092-1106.

KSH (2019): Munkaröpiaci helyzetkép, 2014-2018. Budapest. KSH. Elérhető:

http://www.ksh.hu/docs/hun/xftp/idoszaki/munkerohelyz/munkerohelyz17.pdf (Letöltve: 2021.05.03.)

Leitheiser Fruzsina - Veroszta Zsuzsanna (2021): A várandósok szülés utáni munkavállalási terveit meghatározó tényezők. Demográfia, 63(2-3): 199-228.

Makay Zsuzsanna (2015): Családtámogatás, gyermeknevelés, munkavállalás. In Monostori Judit - Öri Péter - Spéder Zs. (szerk.): Demográfiai portré 2015. Budapest: KSH Népességtudományi Kutatóintézet, 57-74.

Makay Zsuzsanna (2017a): Parental leave and career interruption of mothers in France and Hungary. In Régnier-Loilier, Arnaud (szerk.): A Longitudinal Approach to Family Trajectories in France. The Generations and Gender Survey. Paris: INED/Springer, 173-197. 
Makay Zsuzsanna (2017b): Változnak-e a kisgyermekes anyák munkavállalásával kapcsolatos vélemények Magyarországon? Korfa, 17(5): 1-4.

Makay Zsuzsanna (2018): Kisgyermekes anyák munkavállalása és az ezzel kapcsolatos vélemények változása Magyarországon. Magyar Tudomány, 179(11): 1702-1716.

Makó Ágnes (2018): A nők foglalkoztatására ható jogszabályi környezet. In Fazekas Károly Szabó-Morvai Ágnes (szerk.): Munkaerőpiaci Tükör 2017. Budapest: MTA Közgazdaság- és Regionális Tudományi Kutatóközpont Közgazdaság-tudományi Intézet, 179-184.

Matysiak, Anna - Vignoli, Daniele (2010): Employment around first birth in two adverse institutional settings: Evidence from Italy and Poland. Journal of Family Research, 22(3): 331-349.

Matysiak, Anna - Vignoli, Daniele (2013): Diverse effects of women's employment on fertility: insights from Italy and Poland. European Journal of Population, 29(3): 273302.

McGovern, Patricia - Dowd Bryan - Gjerdingen, D. K. - Moscovice, Ira - Kochevar, Laura Murphy, Sarah (2000): The determinants of time off work after childbirth. Journal of Health Politics, Policy and Law, 25(3): 527-564.

Mincer, Jacob - Polachek, Solomong (1974): Family investments in human capital: earnings of woman. Journal of Political Economy, 82(2/2): S76-S108.

Nagy Adrienn (2021): Családpolitika. T/510. Budapest: Állami Számvevőszék. Elérhető:

https://www.asz.hu/storage/files/files/elemzesek/2021/csaladpolitika_20210126.pdf?ct

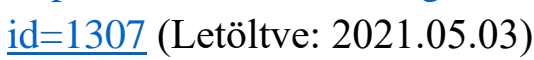

Nemzeti Együttműködés Programja (2010): Elérhető:

https://www.parlament.hu/irom39/00047/00047.pdf (Letöltve: 2021.05.03)

OECD Family Database (2020): LMF1.2. Maternal employment rates. Letöltve: 2021.05.03án: http://www.oecd.org/els/family/LMF1_2_Maternal_Employment.pdf

Percheski, Christine (2008): Maternal Employment After a Birth: Examining Variations by Family Structure. Working Paper 08-18-FF, Princeton: Center for Research on Child Wellbeing.

Pongrácz Tiborné - S. Molnár Edit (2011): A nemi szerepmegosztásról, a családi élet és a munka összhangjáról alkotott vélemények változása 2000-2009 között. In Pongrácz Tiborné (szerk.): A családi értékek és a demográfiai magatartás változásai. KSH NKI Kutatási jelentések 91. Budapest: KSH Népességtudományi Kutatóintézet, 95-111.

R. Fedor Anita - Takács Péter (2013): A gyermekgondozási szabadság optimális időtartama. Acta Medicinae et Sociologica 3: 65-78. 
R. Fedor Anita - Toldi Andra (2017): Labour market opportunities of women with young children after childbirth. Kontakt, 19(3), 236-243.

R. Fedor Anita (2015): Egyensúlyban? - A munkaeröpiaci karriertöl a familiarizmusig. Debrecen: Debreceni Egyetemi Kiadó.

Spéder Zsolt - Murinkó Lívia - Oláh Sz. Livia (2019): Cash support vs. tax incentives: the differential impact of policy interventions on third births in contemporary Hungary. Population Studies, 74(1): 39-54.

Veroszta Zsuzsanna (2018): Kutatási koncepció. Kohorsz '18 Magyar Születési Kohorszvizsgálat. KSH NKI Kutatási Jelentések 100. Budapest: KSH Népességtudományi Kutatóintézet.

Vignoli, Daniele (2011): Human capital and entry into motherhood in Italy. Università de Firenze, Dipartimento di Statistica G. Parenti, Working Paper 2011/06. 